Man and Nature

L'homme et la nature

\title{
Thomas Warton's Gothic Sensibility
}

\section{Edward J. Rielly}

Volume 10, 1991

URI : https://id.erudit.org/iderudit/1012631ar

DOI : https://doi.org/10.7202/1012631ar

Aller au sommaire du numéro

Éditeur(s)

Canadian Society for Eighteenth-Century Studies / Société canadienne d'étude du dix-huitième siècle

ISSN

0824-3298 (imprimé)

1927-8810 (numérique)

Découvrir la revue

Citer cet article

Rielly, E. J. (1991). Thomas Warton's Gothic Sensibility. Man and Nature /

L'homme et la nature, 10, 147-158. https://doi.org/10.7202/1012631ar

Copyright (c) Canadian Society for Eighteenth-Century Studies / Sociéte canadienne d'étude du dix-huitième siècle, 1991
Ce document est protégé par la loi sur le droit d'auteur. L'utilisation des services d'Érudit (y compris la reproduction) est assujettie à sa politique d'utilisation que vous pouvez consulter en ligne.

https://apropos.erudit.org/fr/usagers/politique-dutilisation/ 


\section{Thomas Warton's Gothic Sensibility}

Thomas Warton was an ardent antiquarian who contributed significantly to the late eighteenth century fusion of the antiquarian and the man of taste (the latter the discerning critic or editor whose successful enterprises depend on the former's diligence and judgment). ${ }^{1}$ Warton, of course, was also much more than an antiquarian, even more than an antiquarian of taste. He was a poet, literary historian, critic, and editor. This paper is concerned not only with Warton's antiquarianism, but also with what bound together Warton's many activities. This common, synthesizing link was his abiding love for the distant past, more specifically his Gothic sensibility; and virtually all of his interests, personal and professional, manifested that sensibility. His study of literature reflected this attitude, as in the famous passage from the first edition of Observations on the Faerie Queene of Spenser, in which he emphasized his conviction that an adequate understanding of earlier literature (which on the whole he much preferred to contemporary literature) depends on a careful study of the past:

In reading the works of an author who lived in a remote age, it is necessary, that we should look back upon the customs and manners which prevailed in his age; that we should place ourselves in his situation, and circumstances; that so we may be the better enabled to judge and discern how his turn of thinking, and manner of composition were biass'd by ... familiar and reigning appearances, which are utterly different from those with which we are at present surrounded. ${ }^{2}$

Warton happily lived out this concept of self-placement in the past. Oxford, where he dwelt from the age of sixteen until his death over forty-five years later, gave him an ideal setting for this effort, with its Gothic architecture and illustrious history, extending through legend back to King Alfred. ${ }^{3}$ For Warton, vocation and avocation coalesced, even during summer vacations when he traveled the countryside visiting ancient buildings, often urging owners to preserve their old edifices from destruction. ${ }^{4}$ 
Buildings (and, of course, poems) were the ancient monuments Warton most valued. 'The Pleasures of Melancholy,' which he wrote at about the age of seventeen, includes generalized references to Gothic architecture: a 'ruin'd abbey's moss-grown piles' and 'Gothic vaults' (11. 28, 204). ${ }^{5}$ Although most of the poem is the sentimental posturing of a talented but immature poet, the interest in Gothic architecture would endure. Only a few years later, in 1750, Thomas Warton published $A$ Description of the City, College, and Cathedral of Winchester. ${ }^{6}$ Portions of the book are almost unreadable, particularly the lengthy accounts of Latin inscriptions from urns, brass floor plates, marble tables, monuments, and doors in the college chapels (28-43, 46-61). Nonetheless, Warton exhibits a keen observer's eye and an antiquarian's heart in the volume, even if he has not yet become very discriminating in his antiquarianism. There is also that interest in windows about which Warton's editor, Richard Mant, asserts, It may be difficult to mention any distinguishing feature in that branch of Gothic architecture ["the Gothic window"], which Warton has not noticed' (1: 133-34n.). ${ }^{7}$

Warton would go on to write much more about Gothic architecture. He added an essay on the history of Gothic architecture to the second edition of the Observations on the Fairy Queen, ${ }^{8}$ a survey that offers little of importance today on the subject but was well respected in its time. ${ }^{9}$ Warton openly admits his inadequate preparation for such a survey, citing unfamiliarity 'with the terms and principles of architecture' (2: 198).

Warton's many poems that refer to Gothic structures include 'The Triumph of Isis,' 'The Grave of King Arthur,' 'Newmarket, A Satire,' 'On the Birth of the Prince of Wales,' 'Ode for the New Year, 1788,' 'Ode Written at Vale-Royal Abbey in Cheshire,' 'Ode for Music,' and the sonnet 'On King Arthur's Round Table.' Warton planned to write a substantial work entitled Observations, Critical and Historical, on Churches, Monasteries, Castles and Other Monuments of Antiquity, even announcing in his History of English Poetry that the work was nearly ready for publication. ${ }^{10}$ Unfortunately, the manuscript was either lost or never written.

Specimen of a History of Oxfordshire is yet another reflection of Warton's Gothic interests. It initially appeared as a pamphlet in 1782, with only twenty copies issued, ${ }^{11}$ followed in 1783 by an enlarged edition. ${ }^{12}$ The Specimen is a history of the parish of Kiddington, assigned to Warton as a living in 1771. The Specimen, which Warton hoped to see become part of a comprehensive history of Oxfordshire, ${ }^{13}$ is much better written than the earlier Description of ... Winchester. As a contribution toward Warton's antiquarian views, the work is especially important for its preface, in which Warton offers his opinions on local histories and, by extension, on 
antiquarian writings. Warton cites 'the prevailing opinion of the world, that these performances are solely fabricated on the petty diligence of those unaspiring antiquaries, who employ their time in collecting coats of arms, poring over parish-registers, and transcribing tombstones', (iii). Warton could have been thinking of himself at an earlier age, though instead heimplicitly places himself in a far different rank with theopinion that in the hands of a sensible and judicious examiner, they are the histories of antient manners, arts and customs' (iii). Warton goes on to offer a rationale for antiquarian efforts, 'that general knowledge is to be drawn from particularities' (iv); and this 'general knowledge,' to repeat Warton's words, is of 'antient manners, arts, and customs.' In short, antiquarian efforts should be productive and useful. Not an end in itself, antiquarianism should serve the larger purpose of demonstrating how earlier people lived, thought, and created works of art.

A prominent example of the usefulness of Warton's type of antiquarianism (and a testimony to his critical integrity) occurs when he puts his knowledge of 'antient manners, arts, and customs' to use in attempting a solution to the Chatterton controversy. ${ }^{14}$ Warton's passion for the past caused him to wish that the poems were genuine, but his fidelity to historical truth compelled him, after a detailed study of the poems, to acknowledge in An Enquiry into the Authenticity of the Poems Attributed to Thomas Rowley that they were spurious. ${ }^{15}$ In the conclusion to his Enquiry, Warton offers a convincing exposition of the need to join strictly antiquarian efforts to taste, judgment, and understanding:

I could mention many other circumstantial evidences relating to the process and management of this forgery. But I do not wish to rest my proof on evidences of this nature. It is not from the complexion of ink or of parchment, from the information of cotemporaries, the tales of relations, the recollection of apprentices, and the prejudices of friends, nor even from doomsday-book, pedigrees in the herald's office, armorial bearings, parliamentary rolls, inquisitions, indentures, episcopal registers, epitaphs, tomb-stones, and brass-plates, that this controversy is to be finally and effectually adjusted. Our arguments should be drawn from principles of taste, from analogical experiment, from a familiarity with antient poetry, and from the gradations of composition. Such a proof, excluding all imposition, liable to no deception, and proceeding upon abstracted truth, will be the surest demonstration. (124)

Thomas Warton observed, of course, that not all antiquarian efforts are useful; many wander into the trivial, some into the absurd. One of Warton's most delightful compositions, A Companion to the Guide and a 
Guide to the Companion: Being a Complete Supplement to all the Accounts of Oxford Hitherto Published, parodies antiquarian writings and travel guides while also having some fun at the expense of Oxford itself. ${ }^{16}$ The Companion, for example, spoofs antiquarian etymological debates, including the quest for the origin of the name Oxford, settling finally on bullositum as the original name for the city. Warton offers as evidence:

that there are many kindred appellations in and about Oxford, which conduce to illustrate and confirm my hypothesis. Need I mention Bullington Hundred, in which Oxford is situated, Bullock's Lane, and Bullstock Bridge? - Are not our frequent Bullbaitings in Oxford standing memorials of this original Denomination? (6)

Bull, then as now, had the meaning of nonsense; it also meant a jest. In fact, an earlier antiquary well known to Warton, Anthony à Wood, used the term this way in his Oxoniana ('Every one in order was to ... make a jest or bull, or speake some eloquent nonsense, to make company laugh'). ${ }^{17}$

Warton then refers to an observation by Thomas Hearne concerning an old Oxford custom " "of blowing with, and drinking, horns" '; and mentions a ford near Oxford referred to by Hearne as a popular passage for oxen (6-7). Warton claims that Hearne was alluding to the issue at hand (presumably implying that 'oxen's ford' was the original for 'Oxford') and offers a conciliatory suggestion:

Why may we not suppose, by way of reconciling both opinions, that the Ford was common to horned cattle in general? Nay that even Cows had more concern in this case than is commonly supposed, seems very probable from the name of the neighbouring village, Cowley. (6-7)

After this reductio ad absurdum, Warton shares other findings, like his discovery of twelve Oxford halls never before described, among them Cabbage Hall, Caterpillar Hall, Lemon Hall, Tripe Hall, and Kidney Hall (8). He explores a number of ancient edifices, including the remnants of a 'Pennyless-Bench' upon which 'many eminent Poets have been Benchers' (15); and a mysterious water pump with two heads on top and one spout. Warton conjectures that the pump may be a 'genuine Roman Priapus,' but suspects that most likely it 'is a just Matrimonial Emblem; as it plainly exhibits the Faces of a Man and Woman, but of a very sour Aspect, and reverted from each other' (19). 
Warton returns several times to Hearne, including Hearne's statement concerning an almanac, "It is rude, and very little is to be gathered from it: Yet "Tis a Curiosity" ' (30). The statement, with its acknowledgment of indiscriminate and pointless hunting after old things, expresses the potential folly of antiquarians that Warton mentions in the preface to his Specimen of a History of Oxfordshire as the 'petty diligence of those unaspiring antiquaries ...' (iii). In the Observations on the Fairy Queen, Warton refers to 'That laborious antiquary Thomas Hearne' and his 'extreme thirst after antient things,' while letting the antiquarian's own words ridicule him: " "But tho' I have taken so much pleasure in perusing the English bible of the year 1541, yet 'tis nothing equal to that I should take, in turning over that of the year 1539" ' (2: 102n.).

Hearne, of course, is the Wormius satirized by Pope in the third book of The Dunciad:

'But who is he, in closet close y-pent,

Of sober face, with learned dust besprent?'

'Right well mine eyes arede the myster wight,

On parchment scraps y-fed, and Wormius hight.

To future ages may thy dulness last,

As thou preserv'st the dulness of the past! ${ }^{18}$

As The Dictionary of National Biography points out, Hearne lacked the 'power to distinguish the relative value of what fell in his way; it seemed to him enough that a document was old to induce him to publish it. ${ }^{19}$ The complaint against Hearne recalls Warton's reference in his History of English Poetry to those 'antiquaries of former times' who 'employed their industry in reviving obscure fragments of uninstructive morality or uninteresting history' rather than in displaying 'the progress of human manners' and illustrating 'the history of society' (1:209).

After publication of the Companion, Joseph Warton contributed to The Oxford Sausage, which Thomas edited, a poem entitled 'Epistle from Thomas Hearne, Antiquary, to the Author of The Companion to the Oxford Guide. ${ }^{20}$ The poem has Hearne describing Thomas Warton as a former 'Friend of the moss-grown Spire and crumbling Arch' (1.1), and wondering

What malignant Fiend

Thy cloyster-loving Mind, from antient Lore, Hath base seduc'd? Urg'd thy apostate Pen 
To trench deep Wounds on Antiquaries sage,

And drag the venerable Fathers forth,

Victims to Laughter! (11. 3-8)

The poem concludes with an extended curse on the apostate Warton, cleverly hitting him where it hurts most - his love for Gothic buildings:

But now may Curses every Search attend

That seems inviting! May'st thou pore in vain

For dubious Door-ways! May revengeful Moths

Thy Ledgers eat! May chronologic Spouts

Retain no Cypher legible! May crypts

Lurk undiscern'd! Nor may'st thou spell the Names

Of Saints in storied Windows! Nor the Dates

Of Bells discover! Nor the genuine Site

Of Abbot's Pantries! And may Godstowe veil,

Deep from Thy Eyes profane, her Gothic Charms!

(11. 18-27)

Being essentially good-natured, Thomas Warton could laugh at his own inclinations as well as mock the excesses and failures of misguided antiquarianism in others. However, he recognized, as he says in the sonnet 'Written in a Blank Leaf of Dugdale's Monasticon,' that 'the winding ways/Of hoar Antiquity' are 'strown with flowers' (11.13-14). These flowers - the exhibition of 'ancient manners, arts, and customs' - blossom in the same garden that produced the poetry of England's past. Warton consistently believed that literature reflects the manners and values of the age that produced it. In the History of English Poetry, Warton goes so far as to claim that the 'chief source of entertainment which we seek in antient poetry' is 'the representation of antient manners' (2: 264; also 1: 208-09 and Observations 1: 156; 2: 267-68).

Warton intended his History of English Poetry not only as a history of poetry but also as a history of the national genius and character of England, as manifested in its literary productions. ${ }^{21} \mathrm{He}$ speaks, for example, of developing 'the dawnings of genius' and pursuing 'the progress of our national poetry ...' (1: ii). Warton deserves criticism for his omission of Old English poetry, and certainly his remark that 'Saxon poems are for the most part little more than religious rhapsodies' (1: vi) indicates insufficient knowledge about poetry of that period. Yet his primary reason for eliminating the 'Saxon poetry' from his history was that he believed it had little effect on the British national 
character. He writes in the History that the Norman accession 'obliterated almost all relation to the former inhabitants of this island; and produced that signal change in our policy, constitution, and public manners, the effects of which have reached modern times' (1: vi). Seen in this light, the omission at least reflects method, not just ignorance. Further, the position is consistent with Warton's survey of Gothic architecture in Observations on the Fairy Queen, where Warton also begins with the Normans, who, he states, 'introduced arts and civility' into England (2: 185).

Warton draws this national character in his History through three primary manifestations: poetry, manners, and language. He considers poetry, of course, as art; but he also studies poetry for its 'faithfully recording the features of the times, and of preserving the most picturesque and expressive representations of manners: and,' he writes, 'because the first monuments of composition in every nation are those of the poet, as it possesses the additional advantage of transmitting to posterity genuine delineations of life in its simplest stages' (1: ii-iii). He adds, My performance, in its present form ... represents the progression of our language' (1:v). The explicit point of reference is poetry, but the actual subject of his History is multi-faceted.

There is insufficient space in this paper to consider Warton's discussion of language development or his extensive treatment of a wide range of literary topics, among them his important analysis of the periods of English poetry. ${ }^{22}$ It is important, however, to recall here that The History of English Poetry was a monumental undertaking that, regardless of how one evaluates its level of success, was possible because Warton was an antiquarian who also was a scholar, critic, and editor. The editor in Warton is clearly visible in the many long quotations that give the History its near-anthology character. At a time when a great many of the works cited in the History were difficult to come by, that dimension of the study was of great practical value.

It is also worth remembering at this point that Warton's scholarly interest in early poetry and his antiquarianism (most importantly his love for Gothic structures and his explorations into ancient behavior and attitudes) run along parallel lines, both illustrating Warton's love for the past and his interest in ancient compositions as conveyers of ancient manners. Which came first in Warton's life, his fondness for literature or for medieval castles and ruins, is impossible to say. As a child, Thomas Warton spent considerable time exploring in both books and fields. As a clergyman and former Poetry Professor at Oxford, the father, Thomas Warton the Elder, certainly had a ready library for his children. ${ }^{23}$ In addition, the young Thomas visited a range of historic sites with his father, among them Windsor Castle and possibly Stone- 
henge, as well as various ruins, such as the Chapel of the Holy Ghost in their village of Basingstoke and the nearby Basing House at the site of a battle between Danes and Saxons. ${ }^{24}$ There was no lack of influences to wed young Warton to the past.

It is not surprising, then, that the famous 'recantation' in Warton's 'Verses on Sir Joshua Reynolds's Painted Window at New College, Oxford' appears less than sincere. It did not convince Reynolds, although the artist greatly admired the poem. He even wrote to Warton praising the 'Verses' and gently chiding Warton for not using his name in the first edition. Warton subsequently replaced 'artist' near the end of the poem with 'Reynolds' (1. 101).

In the first forty lines, Warton laments that the beauty of the new window has 'ravish' $d$ ' him from his earlier love, Gothic architecture and sculpture. He realizes that he has been 'A faithless truant to the classic page,' but nonetheless loved

\section{To catch the simple chime}

Of minstrel-harps, and spell the fabling rime;

To view the festive rites, the knightly play,

That deck'd heroic Albion's elder day;

To mark the mouldering halls of barons bold,

And the rough castle, cast in giant mould;

With Gothic manners Gothics arts explore,

And muse on the magnificence of yore. (11 9-16)

He adds that he chiefly loved to examine the 'vaulted dome,' the 'fretted shrines,' the 'nooks profound,' and 'Where SUPERSTITION with capricious hand/In many a maze the wreathed window plann'd ...' (11. 23-24). The first section of the poem ends with the poet imploring the classical artist to

spare the weakness of a lover's heart!

Chase not the phantoms of my fairy dream,

Phantoms that shrink at Reason's painful gleam. (11. 36-38)

In the second movement of the poem, beginning at line forty-one, the poet accepts his ravishment by Attic art and acknowledges his earlier complaint to have been mistaken (11.41-44). He commends the design, colors, and figures of the painted window, and adds that 
Sudden, the sombrous imagery is fled,

Which late my visionary rapture fed:

Thy powerful hand has broke the Gothic chain,

And brought my bosom back to truth again. (11. 61-64)

As the poem progresses, Warton fuses aesthetic truth to religious truth, which by its nature he sees as eternal and immutable. He describes this truth to which he has returned:

To truth, by no peculiar taste confin'd,

Whose universal pattern strikes mankind;

To truth, whose bold and unresisted aim

Checks frail caprice, and fashion's fickle claim;

To truth, whose charms deception's magic quell,

And bind coy Fancy in a stronger spell. (11.65-70)

The old windows created by Superstition yield to a new window by a Protestant artist. The old figures and the stories that they convey - the rich prophets, proud saints, false miracles, and Martyrdoms of unenlighten'd days' - no more disgrace the sacred window, but yield to 'Grecian groupes' and the 'warm enamel' in which 'Nature lives' (11. 71-100).

Warton has identified nature with truth, and both with the rational,eternal, and immutable. Of course, Warton believed that Anglican Christianity embodies this eternal truth. Gothic art, on the other hand, as a product of medieval superstition, is based on falsehood. And because falsehood is transitory rather than eternal, the Gothic aesthetic could have only a temporary acceptance. A modern critic must reject it in favor of the productions rooted in truth, such as the painted window by a Christian classicist. The choice ultimately seems dictated more by religious factors than by Gothic and neoclassic aesthetics.

Most of the poem, however, is concerned with aesthetics, and it is that aspect of the poem to which Reynolds responded with gratitude but disbelief:

I owe you great obligations for the sacrifice which you have made, or pretend to have made, to modern art: I say pretend; for though it is allowed that you have, like a true poet, feigned marvellously well, and have opposed the two different styles with the skill of a Connoisseur, yet I may be allowed to entertain some doubts of the sincerity of your conversion. I have no great confidence in the recantation of such an old offender. ${ }^{25}$ 
A more accurate statement of Warton's views on Gothic structures occurs approximately three years after the 'Verses' in a passage not encumbered with the need to make proper religious choices. The statement concerns Milton and appears in Warton's edition of Milton's Poems Upon Several Occasions:

Milton was educated at saint Paul's school, contiguous to the church; and thus became impressed with an early reverence for the solemnities of the antient ecclesiastical architecture, its vaults, shrines, iles, pillars, and painted glass, rendered yet more aweful by the accompaniment of the choral service. Does the present modern church convey these feelings? Certainly not. We justly admire and approve sir Christopher Wren's Grecian proportions. Truth and propriety gratify the judgment, but they do not affect the imagination. ${ }^{26}$

In fact, Thomas Warton could not renounce his love for Gothic architecture without disavowing his life's work, his Oxford home, even his summer tours. All of these efforts and experiences were too closely joined by Warton's great love for the past to permit the removal of any one part. He was an indefatigable explorer of the past who, throughout his life, expressed both his knowledge of the past and his Gothic sensibility in his wide range of activities - as poet, critic, editor, and literary historian.

EDWARD J. RIELLY

Saint Joseph's College

\section{Notes}

1 Joan Pittock, The Ascendancy of Taste: The Achievement of Joseph and Thomas Warton (London: Routledge and Kegan Paul, 1973), 170-73.

2 Thomas Warton. Observations on the Faerie Queene of Spenser (London, 1754), 217. For Warton's contributions toward historical criticism, see Frances Schouler Miller, 'The Historic Sense of Thomas Warton, Junior,' English Literacy History, 5 (1938): 71-92. The belief that the past is significantly different from the present was not nearly as commonly held in the eighteenth century as a twentieth-century reader might think. In fact, belief in the uniformity of human nature through time was still widespread. It is now clear that Warton's departure from this principle was an important step in the rise of historical study in the century. For a discussion of uniform nature and eighteenth-century history, see R.N. Stromberg, 'History in the Eighteenth Century,' Journal of the History of Ideas, 12 (1951), 295-304. 
3 Warton uses this legend of Alfred as the founder of Oxford University in his 'Ode for Music,' 11. 88-99. For Warton's poetry I have used the most definitive edition, The Poetical Works of the Late Thomas Warton, ed. Richard Mant, 2 vols. (Oxford, 1802).

4 Clarissa Rinaker, Thomas Warton: A Biographical and Critical Study, University of Illinois Studies in Language and Literature, 2.1 (Urbana: University of Illinois, 1916), 148-51. A more recent biography is John A Vance, Joseph and Thomas Warton, Twayne's English Authors Series 380 (Boston: Twayne Publishers, 1983). Vance also has produced the very useful Joseph and Thomas Warton: An Annotated Bibliography (New York: Garland Publishing, 1983).

5 A relevant study of the poem is Arthur Fenner, Jr., "The Wartons "Romanticize" Their Verse,' Studies in Philology, 53 (1956): 501-08.

6 Thomas Warton, A Description of the City, College, and Cathedral of Winchester (London, 1750).

7 Mant is quite right. See, for example, Warton's consideration of Gothic windows in A Description of ... Winchester, 18, 21, 27-28, 45, 75, 77, 80-81, 85, 94.

8 Thomas Warton, Observations on the Fairy Queeen of Spenser, 2nd ed., 2 vols. (London, 1762), 2: 184-98.

9 For recent evaluation of Thomas Warton's competence in Gothic architecture, consult Kenneth Clark, The Gothic Revival, 3rd ed. (New York: Holt, Rinehart \& Winston, 1962), 39-41.

10 Thomas Warton, The History of English Poetry, 3 vols. (London, 1774, 1778, 1781), 3 : xxii. Also see Rinaker, 146-147. Useful accounts of Gothic architecture in England include William Anderson, The Rise of the Gothic (Salem, N.H.: Salem House, 1985); and Agnes Eleanor Addison, Romanticism and the Gothic Revival (New York: R.R. Smith, 1938). Clark's book, of course, should be mentioned again here.

11 Thomas Warton, Specimen of A History of Oxfordshire (privately printed, 1782).

12 Specimen of a History of Oxfordshire, 2nd ed, (London, 1783). Subsequent references are to this edition.

13 Warton makes it clear in the preface (vii) that he does not intend to write this history himself.

14 The controversy concerned whether the poems attributed to a fifteenth-century Thomas Rowley were written by Rowley or by the teen-ager, Thomas Chatterton, who claimed to have discovered the poems. The poems were published as Poems, Supposed to Have Been Written at Bristol, by Thomas Rowley, and Others, in the Fifteenth Century (London, 1777).

15 Thomas Warton, An Enquiry into the Authenticity of the Poems Attributed to Thomas Rowley (London, 1782).

16 Thomas Warton, A Companion to the Guide, and a Guide to the Companion (London, 1760).

17 Wood's statement from his Oxoniana, 2: 23; is quoted in The Compact Edition of the Oxford English Dictionary, 2 vols. (New York: Oxford University Press, 1971), 1: 292. Warton's involvement with The Lives of Those Eminent Antiquaries John Leland, Thomas Hearne, and Anthony a Wood, 2 vols. (Oxford , 1772) is examined in Edward J. Rielly, 'Thomas Warton and Other Contributors to The Lives of Those Eminent Antiquaries,' Notes and Queries, N.S. 35 (1988): 188-90. An account of Oxford that remains valuable is A.D. Godley, Oxford in the Eighteenth Century (London: Methuen, 1908). 
18 I have used the short Twickenham Text, The Poems of Alexander Pope, ed. John Butt (New Haven: Yale University Press, 1966).

19 The Dictionary of National Biography, ed. Leslie Stephen and Sidney Lee, 66 vols. (1885-1901; London: Oxford University Press, 1949-50), 9: 337.

20 The Oxford Sausage, ed Thomas Warton, 3rd ed. (Oxford, 1772).

21 Recent examinations of Warton's History include David Fairer, 'The Origins of Warton's History of English Poetry,' Review of English Studies, N.S. 32 (1981): 37-63; portions of ch. 3 in Joel Weinsheimer, Imitation (Boston: Routledge \& Kegan Paul, 1984), 93-172; and Pittock's Ascendancy of Taste, especially ch. 5, 167-214. Slightly earlier is Lawrence Lipking, The Ordering of the Arts (Princeton: Princeton University Press, 1970), 352-404.

22 These issues are addressed in Edward J. Rielly, 'An Ideational Study of Joseph and Thomas Warton,' diss. University of Notre Dame, 1974.

23 Thomas Warton the Elder's poetic reputation has declined in recent years, especially in light of David Fairer's articles showing that many poems previously believed to be his, and published as his in Thomas Warton [the Elder], Poems on Several Occasions (London, 1748); actually were written by his sons Thomas and Joseph. See David Fairer, 'The Poems of Thomas Warton the Elder?' Review of English Studies, N.S. 26 (1975): 287-300, 395-406; and 'The Poems of Thomas Warton the Elder? A Postscript,' Review of English Studies, 29 (1978): 61-65.

24 See Rinaker for a summary of Warton's childhood influences, 12-14.

25 The letter is reprinted in Mant, 1: 1xxx-1xxxi.

26 Thomas Warton, ed., Poems Upon Several Occasions (London, 1785), 90-91n. 